\title{
THE MODAL ANALYSIS OF ROCKS IN THE DWELLING OF POONCH AND SUDHUNHOTI, AZAD JAMMU AND KASHMIR, PAKISTAN
}

\section{${ }^{*}$ Muhammad Yasin ${ }^{1}$, Muhammad Sabir Khan ${ }^{1}$, Muhammad Rustam Khan ${ }^{1}$

\begin{abstract}
${ }^{1}$ Institute of Geology, University of Azad Jammu and Kashmir, Muzaffarabad, 13100, Pakistan.
\end{abstract} *Corresponding author: Rajayasinkhan@gmail.com}

This is an open access article distributed under the Creative Commons Attribution License, which permits unrestricted use, distribution, and reproduction in any medium, provided the original work is properly cited

\begin{tabular}{l}
\hline ARTICLE DETAILS \\
\hline Article history: \\
Received 12 May 2017 \\
Accepted 12 July 2017 \\
Available online 17 October 2017 \\
Keywords: \\
modal analysis, visual acuity, \\
plethora, prodigious, exiguous, \\
stratigraphic sections
\end{tabular}

\begin{abstract}
The aim of current research is to confirm early findings of geologists regarding the abundance of frame work mineralogy such as major minerals, rock fragments, accessory minerals, matrix minerals and cement minerals inside rocks by studying their modal analysis in the dwelling of Poonch and Sudhunhoti, Azad Jammu and Kashmir, Pakistan. For this purpose, the samples were first soaked, etched and stained using different chemicals during thin section preparation. Then, the percentage of frame work minerals was counted under petrographic microscope using visual acuity technique. The study indicates that the varieties of quartz ( $23 \%$ to $45 \%$ ) and feldspar ( $3 \%$ to $13 \%$ ) minerals are in profusion and their plethora inside the rock declared them major minerals. The rock fragments (29\% to 56\%) of igneous (Basalts, granite), sedimentary (limestone, dolomite, mudstone, siltstone, sandstone) and metamorphic (marble, schists and other pelites as well as quartzite) origin also exist in prodigious amount and abound inside rocks. The accessory minerals such as biotite (1\% to $3 \%$ ), muscovite (up to $2 \%$ ), tourmaline (few traces), zircon (1\%), chlorite, hornblende, rutile, hematite and pyrite (each with $1 \%$ to few traces) with exiguous amount form accessories. The clay minerals and mica ( 0 to $16 \%$ ) due to their fine size form the matrix of rocks. The calcite $(6 \%$ to $18 \%)$ and silica (2\% to $3 \%)$ binds matrix and cementing material inside rocks. Furthermore, stratigraphic sections prepared in the area were helpful in understanding the geology of outcrops.
\end{abstract}

\section{INTRODUCTION}

The study area on toposheet number 43/G-9, Survey of Pakistan near Muttail Maira lies at less than $90 \mathrm{~km}$ from Islamabad via Azad Pattan road. The area is known for arduous mountainous ascents, saucer shaped gulch and hamlets in the Sub-Himalayas of northeastern Pakistan [1]. The sun shines through the haze during worst weather conditions such as summer monsoon and winter snowy season in the most alluring and captivating landscapes. The altitude of region varies from $481 \mathrm{~m}$ to $216,3 \mathrm{~m}$ (Figure 1) as shown on Digital Elevation Model (DEM). The aim of the current research is to confirm early finding of geologists regarding the abundance of frame work mineralogy such as major minerals, rock fragments, accessory minerals, matrix minerals and cement minerals inside rock by studying their modal analysis in the dwelling of Poonch and Sudhunhoti, Azad Jammu and Kashmir, Pakistan.

\section{PREVIOUS WORK}

Some of the researcher has carried out the geology of few regions and adjoining areas before present work [2-5].

\section{GEOLOGICAL SETTINGS}

The Himalayas are formed as a result of convergence of Indian plate with Eurasian plate. The study area is the part of Sub-Himalayas. The rocks sequence exposed in the Sub-Himalayas are folded neogene molasse type sediments derived from epirogenic upliftment of Himalayas [6]. The SubHimalayas are bounded by Main Boundary Thrust (MBT) towards the north and Himalayan Frontal Thrust (HFT) towards the south [7]. The area has active response towards the tectonic activities. The rock units in the project area have many folds, fault and fractures. The rock formations exposed in the area includes Murree Formation, Nagri Formation, Dhok Pathan Formation and Quarternary alluvial deposits. The measured stratigraphic sections of Murree and Nagri Formations of the area are shown in Figure 3.

\section{MATERIALS AND METHODS}

The 30 rock samples selected for petrography were positioned on the Digital Elevation Model (DEM) by means of Global Positioning System (GPS). The soaking of samples with blue epoxy resin following up etching and staining by alizarin-red as well as potassium ferrocyanide for carbonate identification were the common techniques used in the thin section preparation [8]. The percentage of individual mineral specie as well as matrix and cement was determined by the visual acuity under petrographic microscope. On the other hand, the tape-compass-clinometers method was utilized for the preparation of Lithologs in the field. The Lithologs were prepared and further processed on Arc GIS 10.1 software. In section measurement only one limb of the fold and one block of the fault was measured.

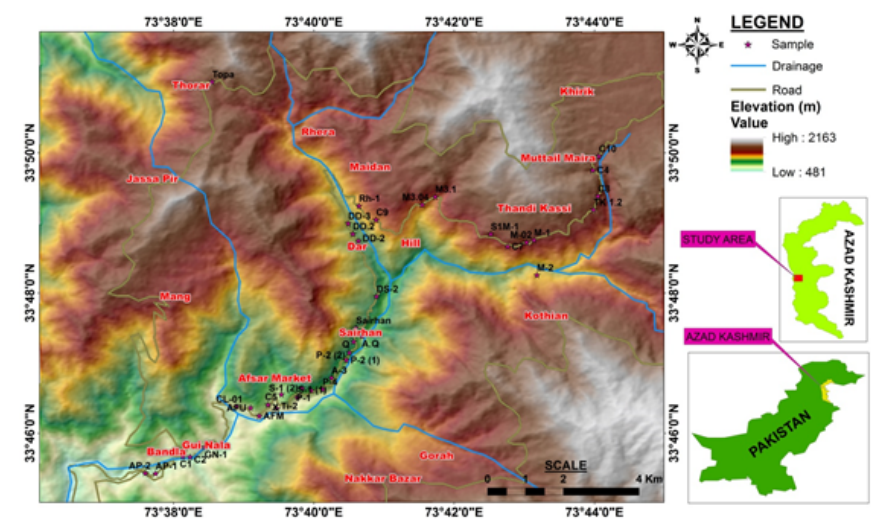

Figure 1: The Digital Elevation Model (DEM) of the project area showing the precise location of each rock sample dislodged from the outcrops for petrographic analysis [9].

\section{RESULTS AND DISCUSSIONS}

The monographic studies enumerated under the Tables $1 \& 2$ have been described in detail below.

Table 1: Showing the modal analysis of the rocks in the dwelling of study area. 


\begin{tabular}{|c|c|c|c|c|c|c|c|c|c|c|c|c|c|c|c|c|}
\hline \begin{tabular}{|l}
$\begin{array}{l}\text { Sample/ } \\
\text { Minerology }\end{array}$ \\
\end{tabular} & \begin{tabular}{|l|}
$\mathrm{TK}$ \\
1.2
\end{tabular} & M-1 & M-2 & \begin{tabular}{|l} 
M- \\
02
\end{tabular} & & \begin{tabular}{|l|}
$\mathbf{M}$ \\
3.04
\end{tabular} & $\begin{array}{l}\text { siM- } \\
1\end{array}$ & $\begin{array}{l}\mathrm{RH}- \\
1-\end{array}$ & DD.2 & & $\begin{array}{l}\text { DD- } \\
3\end{array}$ & DS-2 & \begin{tabular}{|l} 
SIRH \\
AN
\end{tabular} & & Q & 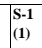 \\
\hline Quartz & $23 \%$ & $31 \%$ & $45 \%$ & $32 \%$ & $45 \%$ & $42 \%$ & $34 \%$ & $43 \%$ & $45 \%$ & $32 \%$ & $34 \%$ & $31 \%$ & $41 \%$ & $29 \%$ & $28 \%$ & $28 \%$ \\
\hline Monocrystalline & $18 \%$ & $24 \%$ & $37 \%$ & $25 \%$ & $38 \%$ & $35 \%$ & $27 \%$ & $36 \%$ & $41 \%$ & $25 \%$ & $27 \%$ & $25 \%$ & $34 \%$ & $23 \%$ & $23 \%$ & $21 \%$ \\
\hline Polycrystalline & $4 \%$ & $5 \%$ & $7 \%$ & $5 \%$ & $5 \%$ & $6 \%$ & $4 \%$ & $5 \%$ & $3 \%$ & $5 \%$ & $4 \%$ & $4 \%$ & $5 \%$ & $4 \%$ & $3 \%$ & $5 \%$ \\
\hline Stretched & $1 \%$ & $2 \%$ & $1 \%$ & $2 \%$ & $2 \%$ & $1 \%$ & $3 \%$ & $2 \%$ & $1 \%$ & $2 \%$ & $3 \%$ & $2 \%$ & $2 \%$ & $2 \%$ & $2 \%$ & $2 \%$ \\
\hline Feldspar & $3 \%$ & $5 \%$ & $9 \%$ & $8 \%$ & $7 \%$ & $9 \%$ & $7 \%$ & $9 \%$ & $7 \%$ & $7 \%$ & $14 \%$ & $7 \%$ & $12 \%$ & $12 \%$ & $11 \%$ & $12 \%$ \\
\hline \begin{tabular}{|l} 
Albite \\
\end{tabular} & - & $3 \%$ & $4 \%$ & $5 \%$ & $2 \%$ & $3 \%$ & $5 \%$ & $4 \%$ & $2 \%$ & $4 \%$ & $8 \%$ & $4 \%$ & $7 \%$ & $6 \%$ & $5 \%$ & $7 \%$ \\
\hline Serthite & $3 \%$ & $2 \%$ & $5 \%$ & $3 \%$ & $4 \%$ & $2 \%$ & - & $2 \%$ & $5 \%$ & - & $2 \%$ & $1 \%$ & $2 \%$ & $3 \%$ & $2 \%$ & $2 \%$ \\
\hline Microdine & - & - & - & - & - & $4 \%$ & $2 \%$ & $2 \%$ & - & $3 \%$ & $3 \%$ & $1 \%$ & $3 \%$ & $2 \%$ & $3 \%$ & $3 \%$ \\
\hline Microperthite & - & - & I- & $1^{-}$ & - & - & $5^{-}$ & $1 \%$ & - & - & - & $1 \%$ & - & $1 \%$ & - & $1-$ \\
\hline Orthodase & - & $1-$ & - & - & $1 \%$ & - & $1^{-}$ & - & - & - & $1 \%$ & - & - & I- & - & $1-$ \\
\hline Plagioclase & $1-$ & $1-$ & - & - & $1-$ & - & $1-$ & - & - & - & - & $1-$ & - & - & $1 \%$ & - \\
\hline Rock fragments & $56 \%$ & $47 \%$ & $34 \%$ & $45 \%$ & $32 \%$ & $32 \%$ & $39 \%$ & $32 \%$ & $35 \%$ & $43 \%$ & $39 \%$ & $39 \%$ & $32 \%$ & $40 \%$ & $34 \%$ & $39 \%$ \\
\hline $\begin{array}{l}\begin{array}{l}\text { Igneous } \\
\text { (Total) }\end{array} \\
\text { (T) }\end{array}$ & $10 \%$ & $4 \%$ & $3 \%$ & $5 \%$ & $4 \%$ & $3 \%$ & $7 \%$ & $10 \%$ & 5\% & $18 \%$ & $14 \%$ & $14 \%$ & $3 \%$ & $17 \%$ & $13 \%$ & $12 \%$ \\
\hline Mafic & $9 \%$ & $4 \%$ & $3 \%$ & $5 \%$ & $4 \%$ & $3 \%$ & $7 \%$ & $9 \%$ & $5 \%$ & $17 \%$ & $12 \%$ & $12 \%$ & $3 \%$ & $15 \%$ & $13 \%$ & $12 \%$ \\
\hline Felsic & - & 1 & - & - & - & - & - & - & - & - & - & - & - & $2 \%$ & - & - \\
\hline Granite & $1 \%$ & - & - & - & - & - & - & $1 \%$ & - & $1 \%$ & $2 \%$ & $2 \%$ & - & 1 & 1 & - \\
\hline Carbonate & $33 \%$ & $21 \%$ & \begin{tabular}{|l|l|}
$16 \%$ \\
\end{tabular} & $12 \%$ & $16 \%$ & $15 \%$ & $7 \%$ & $13 \%$ & $12 \%$ & $9 \%$ & $10 \%$ & $10 \%$ & $11 \%$ & $11 \%$ & $7 \%$ & $10 \%$ \\
\hline Limestone & $26 \%$ & $18 \%$ & $14 \%$ & $12 \%$ & $13 \%$ & $15 \%$ & $7 \%$ & $13 \%$ & $9 \%$ & $9 \%$ & $10 \%$ & $9 \%$ & $9 \%$ & $7 \%$ & $5 \%$ & $10 \%$ \\
\hline Dolomite & $7 \%$ & $3 \%$ & $2 \%$ & - & $3 \%$ & - & - & - & $3 \%$ & - & - & $1 \%$ & $2 \%$ & $3 \%$ & $2 \%$ & 1 \\
\hline Marble & - & 1 & - & - & - & - & - & - & - & - & - & - & - & $1 \%$ & - & $1-$ \\
\hline Schist & $7 \%$ & $8 \%$ & $7 \%$ & $19 \%$ & $8 \%$ & $3 \%$ & $19 \%$ & $7 \%$ & $15 \%$ & $12 \%$ & $13 \%$ & $10 \%$ & $13 \%$ & $9 \%$ & $11 \%$ & $10 \%$ \\
\hline $\begin{array}{c}\text { Graphhitic } \\
\text { Schist }\end{array}$ & - & - & - & - & - & - & - & - & - & t & - & $1 \%$ & - & - & - & $1 \%$ \\
\hline Quartzite & $44 \%$ & $3 \%$ & $2 \%$ & $3 \%$ & $1 \%$ & $4 \%$ & $1 \%$ & $2 \%$ & $3 \%$ & $2 \%$ & - & $2 \%$ & $2 \%$ & - & - & $1-$ \\
\hline Mudstone & - & $4 \%$ & $1 \%$ & - & $1 \%$ & $3 \%$ & - & - & - & - & $2 \%$ & $1 \%$ & - & - & $2 \%$ & $3 \%$ \\
\hline 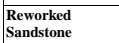 & $1 \%$ & $4 \%$ & $2 \%$ & $3 \%$ & $1 \%$ & $2 \%$ & $1 \%$ & - & - & - & - & - & $2 \%$ & $2 \%$ & - & $2 \%$ \\
\hline Siltstone & $1 \%$ & $3 \%$ & $3 \%$ & $3 \%$ & $1 \%$ & $2 \%$ & $4 \%$ & - & - & $2 \%$ & - & $1 \%$ & $1 \%$ & $1 \%$ & $1 \%$ & $1 \%$ \\
\hline Biotite & $1 \%$ & $2 \%$ & $1 \%$ & $1 \%$ & $2 \%$ & $2 \%$ & $1 \%$ & $1 \%$ & $1 \%$ & $1 \%$ & $2 \%$ & Tr & $2 \%$ & $2 \%$ & $2 \%$ & $1 \%$ \\
\hline Muscovite & $1 \%$ & $1 \%$ & $1 \%$ & $2 \%$ & $1 \%$ & $1 \%$ & $2 \%$ & $1 \%$ & $1 \%$ & $2 \%$ & $1 \%$ & $1 \%$ & $1 \%$ & $1 \%$ & $1 \%$ & $\operatorname{Tr}$ \\
\hline Chlorite & Tr & Ir & & & & - & - & & - & tr & - & $1 \%$ & & Tr & - & $1^{1}$ \\
\hline 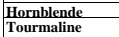 & Tr & tr & & tr & & & & & Tri & $1 \%$ & & $\pi T$ & & $\pi$ & $\frac{1 \%}{10}$ & Tr \\
\hline
\end{tabular}

Table 2: Showing the modal analysis of the rocks in the dwelling of study area.

\begin{tabular}{|c|c|c|c|c|c|c|c|c|c|c|c|c|c|c|}
\hline $\begin{array}{l}\text { Sample/ } \\
\text { Mineralogy \% }\end{array}$ & $\begin{array}{l}\text { s-1 } \\
(2)\end{array}$ & AFM & AFU & Ti-2 & $\mathrm{x}$ & $A-3$ & $\mid \mathbf{P}-2$ (1) & P-2 (2) & $\overline{\text { AP-1 }}$ & \begin{tabular}{|l|l|} 
AP-2 \\
\end{tabular} & $\mathbf{p}-4$ & ${ }_{A}^{\text {TOP }}$ & GN-1 & $\mathbf{p}-\mathbf{1}$ \\
\hline urrz & $30 \%$ & $26 \%$ & $28 \%$ & $27 \%$ & $31 \%$ & $42 \%$ & $29 \%$ & $26 \%$ & $39 \%$ & $40 \%$ & $38 \%$ & $27 \%$ & $32 \%$ & $29 \%$ \\
\hline Gonocrystallinine & $23 \%$ & $18 \%$ & $22 \%$ & $23 \%$ & $22 \%$ & $34 \%$ & $22 \%$ & $18 \%$ & $34 \%$ & 355\% & $31 \%$ & $21 \%$ & $24 \%$ & $20 \%$ \\
\hline 'olycrystalline & $6 \%$ & 6\%\% & 5 & 3\%\% & $7 \%$ & $7 \%$ & $5 \%$ & $6 \%$ & $4 \%$ & $4 \%$ & $5 \%$ & $\frac{14 \%}{4 \%}$ & $6 \%$ & $7 \%$ \\
\hline rretched & $11 \%$ & $2 \%$ & $1 \%$ & $1 \%$ & $2 \%$ & $1 \%$ & $2 \%$ & $2 \%$ & $1 \%$ & $1 \%$ & $2 \%$ & $2 \%$ & $2 \%$ & $2 \%$ \\
\hline eldspar & $12 \%$ & $9 \%$ & $10 \%$ & $8 \%$ & $6 \%$ & $13 \%$ & $9 \%$ & $11 \%$ & $9 \%$ & $13 \%$ & $12 \%$ & $7 \%$ & $12 \%$ & 9\%\% \\
\hline Ilbite & $7 \%$ & $5 \%$ & $5 \%$ & $5 \%$ & $4 \%$ & $7 \%$ & $5 \%$ & $6 \%$ & $4 \%$ & $4 \%$ & $4 \%$ & $15 \%$ & $7 \%$ & $4 \%$ \\
\hline Serthite & $4 \%$ & $2 \%$ & $3 \%$ & $1 \%$ & - & $2 \%$ & $1 \%$ & $3 \%$ & $2 \%$ & $2 \%$ & $3 \%$ & $2 \%$ & $2 \%$ & $2 \%$ \\
\hline nicrocline & $11 \%$ & $2 \%$ & $2 \%$ & $2 \%$ & $1 \%$ & $4 \%$ & $3 \%$ & $2 \%$ & $3 \%$ & $6 \%$ & $5 \%$ & - & $3 \%$ & $3 \%$ \\
\hline Microperthite & - & & $\begin{array}{lll}- & \end{array}$ & - & $1 \%$ & - & - & - & - & $1 \%$ & - & - & & - \\
\hline ithic/Rock & $38 \%$ & $41 \%$ & $37 \%$ & $41 \%$ & $33 \%$ & $29 \%$ & $39 \%$ & $40 \%$ & $32 \%$ & $31 \%$ & $32 \%$ & $42 \%$ & $37 \%$ & $35 \%$ \\
\hline 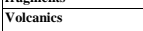 & $15 \%$ & $9 \%$ & $11 \%$ & $7 \%$ & $9 \%$ & $7 \%$ & $6 \%$ & $8 \%$ & $5 \%$ & $9 \%$ & $6 \%$ & $5 \%$ & $10 \%$ & $12 \%$ \\
\hline Metamorphics & - & $31 \%$ & $21 \%$ & 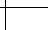 & $21 \%$ & $15 \%$ & $21 \%$ & $19 \%$ & $11 \%$ & - & $22 \%$ & $16 \%$ & $22 \%$ & $10 \%$ \\
\hline 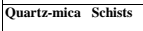 & $14 \%$ & $25 \%$ & $18 \%$ & $11 \%$ & $19 \%$ & $15 \%$ & $18 \%$ & $17 \%$ & $11 \%$ & $12 \%$ & $19 \%$ & $15 \%$ & $19 \%$ & $9 \%$ \\
\hline \begin{tabular}{|l|l} 
Quartzite \\
\end{tabular} & - & $6 \%$ & $3 \%$ & - & $2 \%$ & - & $3 \%$ & $2 \%$ & - & - & $3 \%$ & $1 \%$ & $3 \%$ & $1 \%$ \\
\hline \begin{tabular}{|l} 
Carbonates \\
(Limentone)
\end{tabular} & $6 \%$ & - & $3 \%$ & $22 \%$ & $5 \%$ & $5 \%$ & $9 \%$ & $8 \%$ & $12 \%$ & $9 \%$ & $4 \%$ & $21 \%$ & $5 \%$ & $13 \%$ \\
\hline Dolomite & - & - & - & - & - & - & - & - & $3 \%$ & - & - & - & - & $2 \%$ \\
\hline Silstone & $11 \%$ & $1 \%$ & $2 \%$ & $1-$ & $2 \%$ & - & $1 \%$ & $2 \%$ & $1 \%$ & $\begin{array}{llll}- & \end{array}$ & - & - & - & - \\
\hline Sandstone & $1-$ & - & - & $1 \%$ & $1 \%$ & - & $2 \%$ & $2 \%$ & $1 \%$ & - & - & - & - & - \\
\hline Mudstone & $2 \%$ & $1-$ & $1-$ & $1-$ & - & $2 \%$ & - & $1 \%$ & $2 \%$ & $1 \%$ & $1-$ & $1-$ & 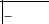 & $\begin{array}{lll}- & \\
\end{array}$ \\
\hline Biotite & - & $1 \%$ & $2 \%$ & $1 \%$ & $2 \%$ & $2 \%$ & $1 \%$ & $1 \%$ & $1 \%$ & $1 \%$ & $2 \%$ & $1 \%$ & $1 \%$ & $3 \%$ \\
\hline Muscovite & $2 \%$ & $1 \%$ & 10 & $1 \%$ & $1 \%$ & $1 \%$ & $1 \%$ & $2 \%$ & $1 \%$ & $1 \%$ & $1 \%$ & $2 \%$ & $1 \%$ & Tr \\
\hline Chlorite & $11 \%$ & "Ir & - & $1-$ & Tr & Tr & $1 \%$ & Tr & - & Tr & Tr & Trt & - & Tr \\
\hline Horrblende & Tr & 5 & Tr & - & Tr & - & - & & $1 \%$ & Tr & Tr & Tr & - & - \\
\hline Tourmaline & - & - & Tr & - & - & - & $\begin{array}{l}- \\
-\end{array}$ & - & - & $\begin{array}{llll}- & & \end{array}$ & ir & Tr & - & - \\
\hline Zircon & - & - & - & - & - & - & - & - & - & $\begin{array}{llll}- & & \end{array}$ & - & - & $1 \%$ & $\left.\right|^{-}$ \\
\hline $\begin{array}{l}\text { Rutile } \\
\end{array}$ & - & - & - & Tr & - & $\left.\right|^{-}$ & - & - & - & - & - & - & - & - \\
\hline Haematite & - & $1 \%$ & Tr & Ir & - & - & - & - & - & - & - & $1 \%$ & - & - \\
\hline Matrix & $11 \%$ & $12 \%$ & $9 \%$ & $10 \%$ & $9 \%$ & $4 \%$ & $8 \%$ & $9 \%$ & $4 \%$ & $4 \%$ & $3 \%$ & $7 \%$ & $6 \%$ & $6 \%$ \\
\hline Cement & $6 \%$ & $9 \%$ & $13 \%$ & $12 \%$ & $13 \%$ & $9 \%$ & $12 \%$ & $511 \%$ & $13 \%$ & $10 \%$ & $12 \%$ & $13 \%$ & $10 \%$ & $18 \%$ \\
\hline Total & $100 \%$ & $100 \%$ & $100 \%$ & $100 \%$ & $100 \%$ & $100 \%$ & $100 \%$ & $100 \%$ & $100 \%$ & $100 \%$ & $100 \%$ & $100 \%$ & $100 \%$ & $100 \%$ \\
\hline
\end{tabular}

\subsection{Sample No. T.K 1.2 Litharenite}

\subsubsection{Microscopic Features}

The sandstone is relatively coarse grained. The quartz grains are highly fractured. The quartz grains form up to $23 \%$ of the rock. The quartz grains are mostly monocrystalline but polycrystalline quartz grains are also present. The monocrystalline quartz grains are up to $18 \%$ and the polycrystalline quartz grains are up to $4 \%$. The stretched quartz grains are up to $1 \%$. The quartz grains have angular and subangular to subrounded outlines. The contacts between quartz grains are tangential. The undulatory extinction (Figure 2C) is also common in most quartz grains.

The mineral feldspar is up to $3 \%$ in abundance. The feldspar includes perthite. The feldspar exhibits myrmekite texture.

The rock fragments are the most dominant constituent of sandstone that forms up to $56 \%$ portion of the rock. The rock fragments include carbonates, volcanics, granite, schists, quartzite, reworked sandstone and siltstone. The carbonate fragments are $33 \%$ in abundance. The carbonate fragments are elliptical, round and oval shaped. Few of the carbonate grains are bioclasts. The bioclasts of the quinqualoculina has been identified. Among carbonates, limestone fragments are most dominant type that forms up to $26 \%$ portion of the rock. The dolomite fragments are up to $7 \%$. The clasts of metamorphic rocks are stretched and foliated. In volcanic rock fragments the plagioclase acts as phenocrysts in fine grained matrix. The schists are up to $7 \%$ while the volcanic rock fragments are up to $9 \%$. The rock fragments of quartzite are up to $4 \%$. The clasts of granite, reworked sandstone and siltstone each forms up to $1 \%$ of the rock.

The opaque mineral hematite is up to $1 \%$. Other minerals include biotite and muscovite. The biotite and muscovite are also up to $1 \%$ and at a par with accessories. The bending of muscovite indicates early diagenetic processes. The tourmaline is present in trace amount.

The litharenite is matrix free. The dominant cementing material is calcite. Rhombohedral cleavage is visible in calcite. The calcite cement is up to $15 \%$.

\subsection{Sample No. M-1 Graywacke}

\subsubsection{Microscopic Features}

The quartz grains are up to $31 \%$ in abundance. The monocrystalline quartz grains are up to $24 \%$ and the polycrystalline quartz grains are up to $5 \%$. The stretched quartz grains are up to $2 \%$. The quartz grains are highly fractured. The polycrystalline quartz grains mostly display undulatory extinction.

The feldspar is up to $5 \%$ in abundance. Of feldspars, albite is at least $3 \%$ while perthite is $2 \%$ in abundance. The feldspar is altered.

The rock fragments are plentiful in rock sample (up to $47 \%$ ). The volcanic rock fragments constitute up to $4 \%$. In volcanic rock fragments plagioclase phenocrysts are embedded in fine grained matrix. The abundance of mica schist's fragments is up to $8 \%$ of the rock. In quartzite rock fragments, the grains are sutured together. The fragments of quartzites are up to $3 \%$. The carbonate clasts of limestone and dolomite are up to $21 \%$. The fragments of limestone form up to $18 \%$ of the rock. The dolomite fragments are up to $3 \%$. The clast of mudstone and siltstone are also abundant. The mudstone is $4 \%$. In mudstone clasts, quartz grains are also visible. The siltstone is up to $3 \%$. The clasts of reworked sandstone are also abundant. The reworked sandstone is up to $4 \%$ in the rock.

The mineral biotite is up to $2 \%$. Most of the biotite is altered into secondary chlorite. The chlorite is found in trace amount. The muscovite is deformed during diagenesis and forms $1 \%$ of the rock. The mineral hematite and tourmaline are present in trace amount. The hornblende forms up to $1 \%$ of the rock.

The clay acts as matrix in greywacke. The matrix is up to $7 \%$. The dominant cementing material is calcite. The calcite cement is up to $6 \%$.

\subsection{Sample No. M-2 Litharenite}

\subsubsection{Microscopic Features}

The plethora of quartz grains (up to $45 \%$ ) forms the bulk composition of rock. The monocrystalline quartz grains are the most dominant. The monocrystalline quartz grains are up to $37 \%$ while the polycrystalline 
quartz grains are up to $7 \%$. The stretched quartz grains are up to $1 \%$. The quartz grains are highly fractured. The quartz grains display both undulatory as well as non-undulatory extinction.

The feldspar is another dominant mineral in sandstone. The feldspar forms up to $9 \%$ portion of the rock. The albite is up to $4 \%$ and the perthite is up to $5 \%$.

The rock fragments are up to $34 \%$ of the rock. The volcanic rock fragments are up to $3 \%$ of the rock. In volcanic rock fragments the plagioclase phenocrysts are embedded in fine grained matrix. The metamorphic clasts of quartz-mica schists are dominant. The quartz-mica schists are forms up to $7 \%$ of the rock. The fragments of quartzite are up to $2 \%$. In the rock fragments of quartzite, the quartz grains are sutured together. Among carbonates, the limestone clasts are dominant. The limestone clast forms up to $14 \%$ of the rock. The clasts of dolomite are $2 \%$. Other rock fragments also include the clasts of reworked sandstone, siltstone and mudstone. The reworked sandstone is up to $2 \%$. The clasts of siltstone are up to $3 \%$ and the mudstone is up to $1 \%$. The mineral biotite and muscovite each forms up to $1 \%$ of the rock.

The clay acts as matrix in lit arenite. The matrix is only $2 \%$. The dominant cementing material is calcite. The calcite cement is up to $8 \%$.

\subsection{Sample No. M-02 Graywacke}

\subsubsection{Microscopic Features}

The quartz grains form up to $32 \%$ portion of the rock. The monocrystalline quartz grains are up to $25 \%$, the polycrystalline quartz grains are up to $5 \%$, while the stretched quartz grains are up to $2 \%$. The contacts between quartz grains are either tangential, point and sutured. The quartz grain varies in size and shape. Some of the grains that came into sight under microscope are rod shaped while the other quartz grains are either very angular, angular to sub round in outline. The quartz grain display undulatory as well as non-undulatory extinction. The overgrowth of calcite around quartz grain is common. The hematite also forms coating around quartz.

The feldspar is either albite or perthite and forms up to $8 \%$ of the rock. The perthite is up to $3 \%$. The albite exhibits lamellar twinning and is up to $5 \%$ in the rock.

The rocks fragments are in profusion (up to 45\%). The volcanic rock fragments forms up to $5 \%$ of the rock. In volcanic rock fragments the plagioclase phenocrysts are embedded in the glassy matrix. The mica schist is up to $19 \%$. The rock fragments of quartzite are up to $3 \%$. In quartzite fragments the quartz grains are sutured togather. The clasts of carbonates form up to $12 \%$ of the rock. Among carbonates, only limestone fragments are visible. The limestone fragments are fractured. The clasts of reworked sandstone and siltstone are also abundant. The reworked sandstone and siltstone each forms up to $3 \%$ of the rock. The muscovite is deformed during diagenesis. The muscovite is up to $2 \%$. The biotite also forms up to $1 \%$ of the rock. Most of the biotite is altered into the chlorite. The tourmaline occurs in trace amount. The opaque mineral hematite forms less quantity (up to $1 \%$ ) in the rock.

The clay acts as matrix in graywacke. The matrix forms up to $7 \%$ of the rock. The dominant cementing material is calcite and is up to $4 \%$ percent of the rock.

\subsection{Sample No. M 3.1 Litharenite}

\subsubsection{Microscopic Features}

The quartz is one of the dominant constituent of sandstone and forms up to $45 \%$ of the rock. The monocrystalline quartz grains are up to $38 \%$ while the polycrystalline quartz grains are up to $5 \%$. The stretched quartz grains are at least $2 \%$. The quartz grains with undulatory as well as nonundulatory extinction are common.

The feldspar forms up to $7 \%$ of the rock. The perthite is up to $4 \%$, the albite is up to $2 \%$ while the orthoclase forms up to $1 \%$ of the rock.

The rock fragments include the clasts of limestone, schists, quartzite, mudstone, reworked sandstone and siltstone. The rock fragments constitute $32 \%$ of the rock. The carbonate fragments are up to $16 \%$, schists are up to $8 \%$, quartzite, mudstone, reworked sandstone and siltstone clasts, each form up to $1 \%$ of the rock. The minerals biotite is $2 \%$ and muscovite is $1 \%$. The muscovite is bent and altered. The heavy mineral zircon occurs in trace amount.

\subsection{Sample No. M 3.04 Litharenite}

\subsubsection{Microscopic Features}

The quartz grains form up to $42 \%$ of the rock. The monocrystalline quartz grains are up to $35 \%$ while the polycrystalline grains are up to $6 \%$. The stretched quartz grains are at least $1 \%$. The quartz grains are angular to sub-angular, sub rounded and elongated. The quartz grains are fractured. The monocrystalline quartz grains display non undulatory extinction while the polycrystalline quartz grains display undulatory extinction. Porosity in quartz is also visible.

The feldspar forms up to $9 \%$ of the rock. The plagioclase feldspar (albite) is up to $3 \%$ while the perthite is up to $2 \%$. The microcline is up to $4 \%$.

The lithic or rock fragments form up to $32 \%$ of the rock. The volcanic rock fragments are up to $3 \%$. In volcanic rock fragments the plagioclase phenocrysts are embedded in fine grained matrix. The quartz-mica schists are up to $3 \%$ by volume. The rock fragments of quartzite are up to $4 \%$. In the rock fragments of quartzite, the quartz grains are sutured. The limestone clasts are up to $15 \%$. The cone in cone structure is visible in limestone clast. The clasts of mudstone, siltstone and sandstone are also present. The clasts of mudstone are up to $3 \%$ while the clasts of siltstone and sandstone each forms up to $2 \%$ of the rock. The minerals biotite and muscovite are also present. The biotite grains are up to $2 \%$. The muscovite is up to $1 \%$. The muscovite is bent and altered. The oblique cleavage is visible in hornblende. The opaque mineral hematite occurs in trace amount.

The clay matrix is present in minor amount. The matrix forms at least $2 \%$ of the rock. The dominant cementing material calcite is up to $12 \%$ of the rock.

\subsection{Sample No. S1M-1 Graywacke}

\subsubsection{Microscopic Features}

The quartz grains form up to $34 \%$ of the rock. The monocrystalline quartz grains are up to $27 \%$. The polycrystalline quartz grains are up to $4 \%$. The stretched quartz grains are up to $3 \%$. The quartz grains display undulatory as well as non-undulatory extinction.

The feldspar forms up to $7 \%$ of the rock. Most of the feldspar grains are altered. The albite is up to $5 \%$ while the microcline is up to $2 \%$. The albite displays lamellar twinning while the microcline displays scotch plaid twinning.

The rock fragments form up to $39 \%$ of the rock. Among metamorphic rock fragments, the quartz-mica schists are the most dominant type that form up to $19 \%$ of the rock. The fragments of quartzite are up to $1 \%$. In quartzite fragments, the quartz grains are sutured togather. The limestone fragments form up to $7 \%$ of the rock. The volcanic rock fragments are up to $7 \%$. The clasts of reworked sandstone and siltstone are also present. The clasts of reworked sandstone and siltstone form up to $1 \%$ and $4 \%$ respectively.

The muscovite is bent and altered and forms up to $2 \%$. The biotite forms up to $1 \%$ of the rock. The opaque mineral haematite forms $1 \%$ of the rock.

The clay matrix in the rock is up to $9 \%$. The calcite occurs up to $5 \%$ and acts as cementing material in the rock.

\subsection{Sample No. Rh-1 Litharenite}

\subsubsection{Microscopic Features}

The quartz grains are by far the most dominant constituent that forms up to $43 \%$ of the rock. The monocrystalline quartz grains are up to $36 \%$ and the polycrystalline quartz grains are up to $5 \%$. The stretched quartz grains are up to $2 \%$ of the rock. The quartz grains display undulatory as well as non-undulatory extinction. The quartz grains are very angular, sub rounded to round in outline. The contacts between quartz grains are either planer, sutured and tangential.

The feldspar grains are up to $9 \%$ of the rock. The plagioclase feldspar (albite) is up to $4 \%$, perthite and microcline each forms up to $2 \%$ of the rock. The micro perthite is up to $1 \%$.

The rock fragments are up to $32 \%$ of the rock. The limestone clasts are up to $13 \%$. The volcanic rock fragments form up to $9 \%$ of the rock. In the volcanic rock fragments, the plagioclase 
phenocrysts are embedded in fine grained matrix. Granite forms up to $1 \%$ and the mica schists form up to $7 \%$ of the rock. The quartzite rock fragments are up to $2 \%$. In quartzite fragments, the quartz grains are strongly sutured together.

The minerals biotite and mineral muscovite each forms up to $1 \%$ of the rock. The heavy mineral zircon occurs in trace amount.

The matrix of lit arenite is mostly formed by the alteration of feldspar and rock fragments. The matrix forms up to $2 \%$ of the rock. The calcite cements form up to $12 \%$ of the rock. Most of the framework grains float in calcite cement.

\section{и}

\section{эger}

The sandstone is highly fractured. The fractures are healed with calcite. The quartz grains form up to $31 \%$ of the rock. The quartz grains are monocrystalline, polycrystalline and stretched. The monocrystalline quartz grains are up to $25 \%$. The polycrystalline quartz grains are up to $4 \%$. The stretched quartz grains are up to $2 \%$. Most of the quartz grains are fractured. The quartz grains are either stretched, straight or elongated, round and sutured. The quartz grains display both undulatory and nonundulatory extinction.

The feldspar forms up to $7 \%$ of the rock. The plagioclase feldspar albite is up to $4 \%$ while the perthite, microcline and micro perthite each form up to $1 \%$ of the rock. Most of the feldspar is altered. Twinning is common in albite, microcline and micro perthite while the perthite exhibits meymacite texture.

The rock fragments form up to $39 \%$ of the rock. The clasts of mafic volcanic rocks are up to $12 \%$. In volcanics rock fragments with the plagioclase phenocrysts are up to $12 \%$. The clasts of felsic plutonic rocks i.e. granite is up to $2 \%$. The metamorphic rock fragments form up to $11 \%$ of the rock. The quartz-mica schists are up to $9 \%$ while graphitic schists are up to $2 \%$. The rock fragments of quartzite are up to $2 \%$. Among sedimentary rock fragments limestone clasts are the dominant type that forms up to $9 \%$ of the rock. The dolomite fragments are $1 \%$ in the rock. The compositional sector zoning is visible in dolomite. The clasts of intraformational siltstone and mudstone are also present. Each form up to $1 \%$ of the rock.

The heavy minerals rutile is up to $1 \%$. The mineral pyrite is found in trace amount. The biotite is present in minor amount. The biotite forms $1 \%$ of the rock. The muscovite is up to $2 \%$. The mineral chlorite is also up to $1 \%$. The mineral hornblende other than volcanic fragments occurs in trace amount.

The clay matrix in rock is up to $8 \%$. The dominant cementing material is calcite. The calcite forms up to $5 \%$ of the rock.

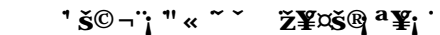

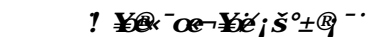

The quartz grains form up to $45 \%$ of the rock. The monocrystalline quartz grains are the most dominant and constitute up to $41 \%$. The polycrystalline quartz grains are up to $3 \%$ while the stretched quartz grains are up to $1 \%$. The quartz grains are either equant or rod-shaped, angular and round. The contacts between quartz grains are suture and tangential.

The feldspar grains form up to $7 \%$ of the rock. The plagioclase feldspar (albite) is up to $2 \%$ while the perthite is up to $5 \%$. The polysynthetic twinning is common in albite.

The rock fragments form up to $35 \%$ of the rock. The metamorphic rocks fragments are up to $18 \%$. The mica schists are the dominant type of metamorphic rock fragments that form up to $18 \%$ of the rock. The rock fragments of quartzite are up to $3 \%$. The mica schists are up to $15 \%$ of the rock. In quartzite fragments, the quartz grains are strongly sutured together. The volcanic rock fragments are up to $5 \%$. In volcanic rock fragments the plagioclase phenocrysts are embedded in fine grained matrix. The limestone fragments are up to $9 \%$. The dolomite is up to $3 \%$. The clasts of reworked sandstone are at least $1 \%$.

The minerals muscovite and biotite each forms up to $1 \%$ of the rock. The biotite and muscovite are deformed during diagenesis.

The clays and chlorite acts as matrix in graywacke. The matrix of sandstone is about $3 \%$. The dominant cementing material is calcite. The calcite forms up to $8 \%$ of rock.

\subsection{Sample No. DD-2 Graywacke}

\subsubsection{Microscopic Features}

The quartz grains form up to $32 \%$ of the rock. The quartz grains are monocrystalline, polycrystalline and stretched. The monocrystalline quartz grains are up to $25 \%$. The polycrystalline quartz grains are up to $5 \%$. The stretched quartz grains are up to $2 \%$. The quartz grains of polycrystalline variety show undulatory extinction. The contacts between quartz grains are suture, point and tangential. Most of the quartz grains are very large and very angular. The quartz gains are highly fractured. The quartz grains display unit extinction. The stylolite texture is also common in the rock.

The feldspar grains are up to $7 \%$. The albite is up to $4 \%$ while the microcline is up to $3 \%$. Lamellar twinning is common in albite while the microcline display scotch plaid twinning.

The rock fragments are most abundant and constitute up to $43 \%$ of the rock. The volcanic rock fragments are up to $17 \%$ and exhibits plagioclase phenocrysts embedded in fine grained matrix. The plagioclase phenocrysts in a few fragments show radiating texture. The rock fragments of granite form up to $1 \%$ of the rock. The carbonates rock fragments form up to $9 \%$ of the rock. Among metamorphic rock fragments, quartz-mica schist and quartzite are the most dominant. Quartz-mica schists form up to $12 \%$ of the rock. The clasts of intraformational mudstone are present. In mudstone, the quartz grains are visible. The clasts of intraformational siltstone and mudstone are $2 \%$ of the rock.

The muscovite is up to $2 \%$ while the biotite is at least $1 \%$. The muscovite is bent during compaction. The biotite is deformed and altered in to chlorite. The mineral hornblende is up to $1 \%$. The mineral chlorite, hematite and zircon are found in trace amount. ,

The matrix of graywacke includes both chlorite and clays. The matrix forms up to $6 \%$ of the rock. The calcite cement is up to $8 \%$.

\subsection{Sample No. DD-3 Graywacke}

\subsubsection{Microscopic Features}

The quartz grains form up to $34 \%$ of the rock. The monocrystalline quartz grains are up to $27 \%$. The polycrystalline quartz grains are up to $4 \%$. The stretched quartz grains form up to $3 \%$ of the rock. The polycrystalline grains are clustered togather like bunches of grapes. The quartz grains display both undulatory as well as non-undulatory extinction. The quartz grains vary in both shape and size. The quartz grains are very angular and sub angular to round in outline. The contacts between quartz grains are suture and point.

The feldspar grains form up to $14 \%$ of the rock. The feldspar grains include albite, microcline, perthite and orthoclase. The albite is up to $8 \%$, perthite is up to $2 \%$, microcline is up to $3 \%$ and the orthoclase forms up to $1 \%$ of the rock. The plagioclase feldspar also shows zoning.

The rock fragments form up to $39 \%$ of the rock. The mafic volcanic rock fragments $(12 \%)$ exhibits plagioclase phenocrysts embedded in fine grained matrix. The clasts of felsic plutonic rocks i.e. granites are up to $2 \%$. Among metamorphic clasts, schists are the most dominant. The schists form up to $13 \%$ of the rock. The carbonate fragments are up to $10 \%$. The clasts of intraformational mudstone are up to $2 \%$.

The mineral biotite and muscovite are present. The biotite is $2 \%$ and the muscovite is $1 \%$ of the rock.

The clay matrix occurs up to $6 \%$ of the rock. The dominant cementing material calcite is up to $4 \%$.

\subsection{Sample No. A.Q Graywacke}

\subsubsection{Microscopic Features}

The quartz grains are monocrystalline, polycrystalline and stretched. Some quartz grains are fractured. The quartz has also embodied the mineral zircon. The quartz grains are up to $29 \%$ of the rock. The polycrystalline quartz grains are up to $4 \%$ and the monocrystalline quartz grains are up to $23 \%$. The stretched quartz grains form up to $2 \%$ of the rock. The quartz grains are very angular to subrounded. The angular quartz grains have bladed margin. Few of the quartz grains have sutured contacts.

The feldspar shows a variety of minerals in the form of albite, perthite, microcline and microperthite. The feldspar is up to $12 \%$. The albite is up to 
$3 \%$, the microcline is up to $2 \%$ while the microperthite forms at least $1 \%$ of the rock. The pericline twinning is common in plagioclase feldspar. The exsolution is common in perthite.

The rock fragments are in profusion and depict a great variety of composition, hence, most dominant. Among rock fragments, the clasts of dolomite, reworked sandstone, limestone, marble, siltstone, metamorphics and volcanics are abundant. The clasts of reworked sandstone are up to $2 \%$, the intraformational siltstone are up to $1 \%$ while the limestone fragments form up to $7 \%$ of the rock. The bioclasts (Figure 2D) are visible in limestone fragments. The rock

fragments of dolomite are up to 3\% in the rock. In dolomite the rhombs and scars are visible. The rock fragments of marble are at least $1 \%$. The hornblende is found either in volcanic rock fragments or exists in isolation as a mineral grain. The hornblende other than volcanic rock fragments is found in trace amount. The volcanic rock fragments are up to $17 \%$. In the volcanic rock fragments plagioclase phenocrysts are embedded in fine grained matrix. The volcanic rock fragments are either mafic or felsic. The mafic volcanic clasts are up to $15 \%$ while the felsic plutonic clasts form up to $2 \%$ of the rock. The fragments of granite are an example of felsic plutonic rock. The clasts of granite form up to $2 \%$ of the rock.

The biotite is up to $2 \%$ while the chlorite is up to $1 \%$. The muscovite forms up to $1 \%$ of the rock. The muscovite is deformed and altered. The sericite also forms a scanty amount (up to $1 \%$ of the rock). The mineral hornblende is scarce and exists in trace amount. The heavy mineral zircon is sparse and also found in trace amount. The replacement of quartz by carbonates is common.

The clay acts as matrix in greywacke. The matrix is up to $7 \%$. Silica acts as cement in few grains. However, the dominant cementing material calcite is up to $6 \%$. While only $3 \%$ fine grained silica acts as cement. The fine-grained silica is pore filling cherty.

\subsection{Sample No. Q Graywacke}

\subsubsection{Microscopic Features}

The quartz grains form up to $28 \%$ of the rock. The quartz grains are monocrystalline with subordinate polycrystalline and some stretched crystals of quartz. The monocrystalline quartz grains are up to $23 \%$, the polycrystalline quartz grains are up to $3 \%$ and the stretched quartz grains form up t o $2 \%$ of the rock. Most of the quartz grains are highly fractured. The contacts between quartz grains are sutured and planer.

The feldspar forms up to $11 \%$ of the rock. The albite is up to $5 \%$ while the perthite is $2 \%$ and microcline forms up to $3 \%$ of the rock. Twinning is common in albite and microcline. Zonning is common in plagioclase feldspar (1\%).

The rock fragments are sufficient and form up to $34 \%$ of the rock. The volcanic rock fragments in the rock with plagioclase phenocrysts embedded in the fine-grained matrix are up to $13 \%$.

Among metamorphic rock fragments, the mica-schists are most dominant. The mica-schists are strongly foliated. The schists are up to $11 \%$. The carbonate rock fragments are up to $7 \%$. The clasts of limestone are up to $5 \%$. The rock fragments of dolomite are up to $2 \%$. The clasts of intraformational siltstone and mudstone are present in minor amount. The siltstone clasts are up to $1 \%$ while the mudstone clasts form up to $2 \%$ of the rock.

The accessory minerals (hornblende, biotite and muscovite) are found in exiguous amount. The mineral hornblende forms up to $1 \%$ of the rock. In hornblende the oblique cleavage is visible. The biotite is up to $2 \%$. Most of the biotite is altered into chlorite and also shows inclusion of tourmaline. The mineral muscovite is up to $1 \%$. The muscovite grains are bent and altered.

The sericitation (Figure 2F) forms up to $16 \%$ clay matrix in the rock. The dominant cementing material is calcite. The calcite has rhombohedral cleavage and occurs up to $7 \%$.

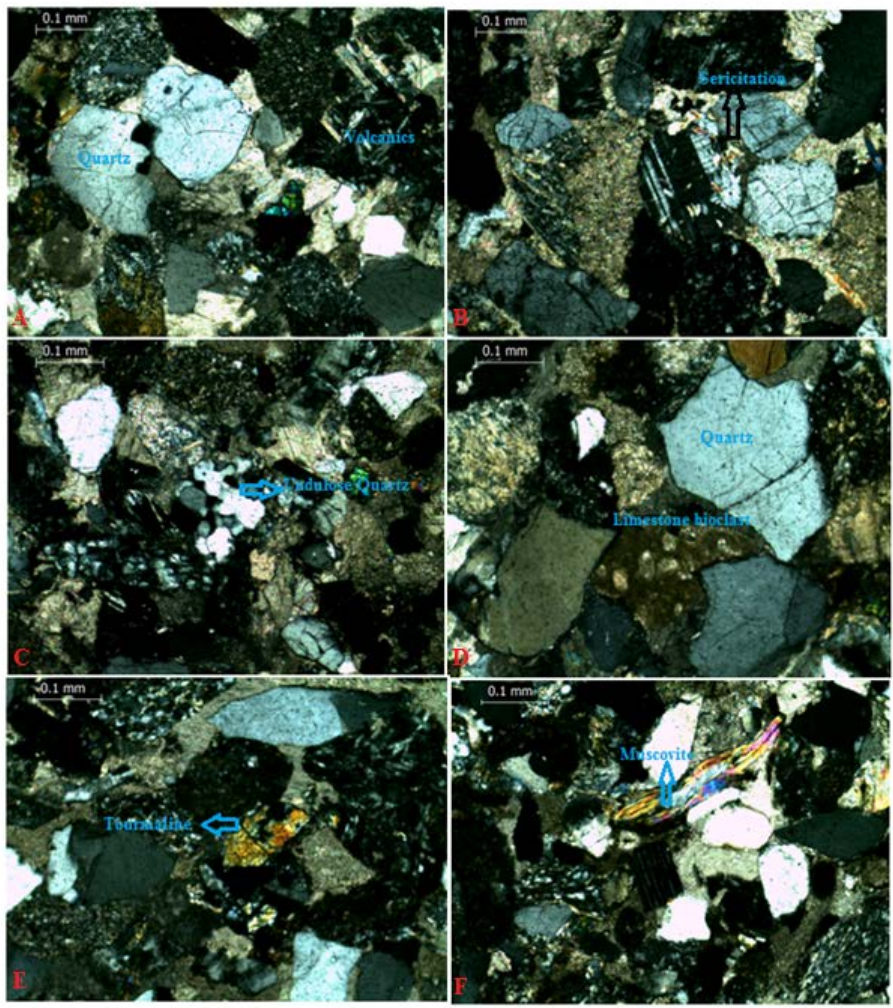

Figure 2: Photomicrographs showing (A) mineral quartz and volcanic rock fragments, (B) Sericitation of muscovite, (C) Quartz grain with undulose extinctions, (D) Limestone bioclasts, (E) Tourmaline, (F) Deformed muscovite.

\subsection{Sample No. Sairhan Graywacke}

\subsubsection{Microscopic Features}

The quartz grains form a prodigious amount (up to $41 \%$ of the rock). The monocrystalline quartz grains are up to $34 \%$ and the polycrystalline quartz grains form $5 \%$ of the rock. The stretched quartz grains form up to $2 \%$ of the rock. The quartz grains are fractured. Most of the quartz grains are elongated. The contacts between quartz grains are tangential.

The feldspar grains form up to $12 \%$ of the rock. The albite is up to $7 \%$, the microcline is up to $3 \%$ while the perthite forms up to $2 \%$ of the rock. Most of the feldspar grains are altered in to clay minerals.

Rock fragments are the most abundant and constitutes up to $32 \%$ of the rock. The carbonate rock fragments are up to $11 \%$. Among carbonate rock fragments, the limestone is dominant. The limestone fragments are up to $9 \%$, while the dolomite is up to $2 \%$. The mica-schists clasts are up to $13 \%$. The volcanic rock fragments form up to $3 \%$ of the rock. In volcanic rock fragments the plagioclase phenocrysts are embedded in the fine-grained matrix.

The mineral muscovite is $1 \%$. Most of the muscovite is deformed during diagenesis. The relative abundance of biotite is up to $2 \%$.

The clay acts as matrix in sandstone. The matrix forms up to $7 \%$ of the rock. The dominant cementing material is calcite. The calcite is up to $5 \%$.

\subsection{Sample No. S-1 (1) Graywacke}

\subsubsection{Microscopic Features}

The quartz grains are fractured. The quartz grains form up to $28 \%$ of the rock. The monocrystalline quartz grains are common and constitute $21 \%$ of the rock. The polycrystalline quartz grains are up to $5 \%$ while the stretched quartz grains form up to $2 \%$ of the rock. The quartz grains with undulatory and non-undulatory extinction are common.

The feldspars form up to $12 \%$ of the rock. The albite is up to $7 \%$, the perthite is up to $2 \%$ while the microcline forms up to $3 \%$ of the rock. Most of the feldspar grains are altered in to secondary minerals.

The rock fragments are the most dominant constituents of sandstone that form up to $39 \%$ of the rock. The volcanic rock fragments are up to $12 \%$. In volcanic rock fragments the plagioclase phenocrysts are embedded in the 
fine-grained matrix. Among metamorphic rock fragments, the quartz mica schists are dominant constituent of sandstone that form up to $11 \%$ of the rock. The graphitic schist is up to $1 \%$. The limestone fragments are up to $10 \%$ in the rock. The rock fragments of mudstone and reworked sandstone are also abundant. The rock fragments of mudstones are up to $3 \%$, reworked sandstones are up to $2 \%$ and intraformational siltstones (1\%) are present in the rock.

The chlorite grains form at least $1 \%$ of the rock. The hornblende occurs in trace amount. The biotite grains form up to $1 \%$ while the muscovite forms the scanty amount (few traces).

The clay acts as matrix in sandstone. The matrix forms up to $15 \%$ of the rock. The calcite cement is up to $4 \%$ in the rock.

\subsection{Sample No. S-1 (2) Graywacke}

\subsubsection{Microscopic Features}

The quartz grains are mostly fractured, very angular and angular to round. The quartz is monocrystalline, polycrystalline and stretched. The contacts between quartz grains are either planer, sutured and tangential. The quartz grains form up to $30 \%$ of the rock. The monocrystalline quartz grains are up to $23 \%$, the polycrystalline quartz grains are up to $6 \%$ while the stretched quartz grains form up to $1 \%$ of the rock.

The feldspar forms up to $12 \%$ and includes albite up to $7 \%$, perthite up to $4 \%$ and microcline up to $1 \%$. Alteration is common in feldspar.

The rock fragments form up to $38 \%$ of the rock. The rock fragments of volcanic, metamorphics, carbonates, mudstone, siltstone and reworked sandstone are abundant. The rock fragments of mafic volcanic rocks are up to $15 \%$. The rock fragments of quartz mica schists are up to $14 \%$. The limestone fragments form up to $6 \%$ of the rock. The clasts of intraformational mudstone are up to $2 \%$ while the clasts of siltstone are up to $1 \%$.

The mineral chlorite forms at least $1 \%$ of the rock. The muscovite is deformed and altered. The muscovite is also at least $2 \%$. The hornblende occurs in trace amount.

The matrix of sandstone is mostly formed by disintegration of quartz, chlorite and rock fragments. The clay contents are also present. The matrix of sandstone is up to $11 \%$. The dominant cementing material is calcite. The calcite occurs as cement in the rock and constitute up to $6 \%$.

\subsection{Sample No. AFM Graywacke}

\subsubsection{Microscopic Features}

The monocrystalline, polycrystalline and stretched quartz grains are present in the rock. The quartz grains are rounded, subrounded to very angular. The contact between quartz grains is planer, suture and tangential and the mineral forms up to $26 \%$ of the rock. The monocrystalline quartz grains are up to $18 \%$, the polycrystalline grains are up to $6 \%$ and the stretched quartz grains form up to $2 \%$ of the rock. Similarly the quartz grains display both undulatory as well as non-undulatory extinction.

The feldspar grains form up to $9 \%$ of the rock. The albite is up to $5 \%$ while the perthite and the microcline each forms up to $2 \%$ of the rock. Most of the feldspar grains are altered.

The rock fragments are most dominant constituents of sandstone that form up to $41 \%$ of the rock. The rock fragments of mafic volcanic rocks are up to $9 \%$. In the volcanic rock fragments the plagioclase phenocrysts are embedded in the fine grained matrix. The metamorphic rock fragments are up to $31 \%$. The quartz mica schists form up to $25 \%$ of the rock. The rock fragments of quartzite are up to $6 \%$ in the rock. In quartzite fragments, the quartz grains are sutured togather. The clasts of intraformational siltstones are $1 \%$.

The mineral biotite is $1 \%$ in the rock. The mineral muscovite is up to $1 \%$. Most of the muscovite grains are deformed and altered. The chlorite and hornblende occurs in small amount. The opaque mineral like hematite is up to $1 \%$ in the rock.

The clay matrix in sandstone is up to $12 \%$. The calcite cement is up to $9 \%$.

\subsection{Sample No. AFU Graywacke}

\subsubsection{Microscopic Features}

The quartz in the rock occurs as monocrystalline, polycrystalline and stretched variety. The contacts between quartz grains are planer, sutured and tangential. The undulatory as well as non-undulatory extinctions are common in quartz grain. The quartz grains form up to $28 \%$ of the rock. The monocrystalline quartz grains are up to $22 \%$ while the polycrystalline quartz grains are up to $5 \%$. The stretched quartz grains form up to $1 \%$ of the rock. The majority of quartz grains are very angular.

The feldspar grains form up to $10 \%$ of the rock. The albite is up to $5 \%$, the perthite is up to $3 \%$ and the microcline forms up to $2 \%$ of the rock. Twinning is most common in microcline and plagioclase feldspars.

The rock fragments are the most dominant constituent of sandstone that form up to $37 \%$ of the rock. Among rock fragments, the metamorphic rock fragments are most abundant. The metamorphic rock fragments are up to $21 \%$ in the rock. The clasts of quartz-mica schists are up to $18 \%$. The quartz sutured quartzite fragments are up to $3 \%$ in the rock. In volcanic rock fragments the plagioclase phenocrysts are emplaced in the fine-grained matrix. The mafic volcanic rock fragments form up to $11 \%$ of the rock.

Minor amount of chlorite is found in volcanic rock fragments. The limestone fragments are up to $3 \%$. The clasts of intraformational siltstone are atleast $2 \%$. The mineral biotite forms up to $2 \%$ of the rock. The bending of muscovite grain (Figure 2F) is either diagenetic change or the product of tectonic strain. The muscovite is at least $1 \%$. The hornblende and tourmaline (Figure 2F) occurs in trace amount while the heavy mineral hematite is at least $1 \%$.

The matrix of sandstone has a composition of clays. The matrix is up to $9 \%$ of the rock. The calcite cement is up to $12 \%$.

\subsection{Sample No. Ti-2 Graywacke}

\subsubsection{Microscopic Features}

The quartz grains are monocrystalline, polycrystalline and stretched. The quartz grains are fractured. The quartz grains are very angular to sub angular and round. The quartz grains display both undulatory as well as non-undulatory extinction. The quartz grains form about $27 \%$ of the rock. The monocrystalline quartz grains are up to $23 \%$. The polycrystalline quartz grains are up to $3 \%$. The stretched quartz grains form at least $1 \%$ of the rock.

The feldspar is $8 \%$ of the rock and includes albite up to $5 \%$, perthite up to $1 \%$ and microcline up to $2 \%$ of the rock. Twinning is common in albite.

The rock fragments are the most dominant constituent that form up to $41 \%$ of the rock. The volcanic fragments are up to $7 \%$ and include the plagioclase phenocrysts emplaced in the fine-grained matrix. The limestone fragments form up to $22 \%$ of the rock. The strongly foliated quartz-mica schists form up to $11 \%$ of the rock. Among siliciclastic rock fragments, the clasts of reworked sandstone are present. The sandstone fragments form up to $1 \%$ of the rock.

The mineral biotite and muscovite each with $1 \%$ abundance are found in the rock. The muscovite is deformed. The mineral hornblende is found in trace amount. The hematite and rutile both occurs in trace amount.

The matrix of sandstone is up to $10 \%$. The clay acts as matrix in sandstone. The calcite cement is up to $12 \%$ in the rock.

\subsection{Sample No. A-3 Litharenite}

\subsubsection{Microscopic Features}

The quartz grains are monocrystalline, polycrystalline and stretched. Quartz grains have developed suture, planer and tangential contacts between them. The quartz grains display both undulatory as well as non-undulatory extinction. The quartz grains are up to $42 \%$. The monocrystalline quartz grains are up to $34 \%$, the polycrystalline quartz grains are up to $7 \%$ and the stretched quartz grains form up to $1 \%$ of the rock.

The feldspar is up to $13 \%$ and includes albite, microcline and perthite. The albite is up to $7 \%$, the perthite is up to $2 \%$ and the microcline forms up to $4 \%$ of the rock. In albite, twinning is common.

The rock fragments include the clasts of mafic volcanic, schists, limestone and mudstone. The rock fragments form up to $29 \%$ of the rock. In volcanic 
rock fragments are up to $7 \%$ of the rock. The limestone fragments form up to $5 \%$ of the rock. The mudstone fragments are up to $2 \%$ in the rock. The quartz grains are visible on the surface of mudstone. The quartz mica schists form up to $15 \%$ of the rock.

The mineral chlorite and hornblende are found in trace amount. The biotite forms up to $2 \%$ of the rock. The muscovite grains are bent and are up to $1 \%$.

The clay matrix forms up to $4 \%$ of the rock. The calcite acts as cementing material in sandstone and is up to $9 \%$ of the rock.

\subsection{Sample No. X Graywacke}

\subsubsection{Microscopic Features}

The quartz grains form up to $31 \%$ of the rock. The quartz grains are either monocrystalline, polycrystalline and stretched. The monocrystalline quartz grains are up to $22 \%$, the polycrystalline quartz grains are up to $7 \%$ while the stretched quartz grains form up to $2 \%$ of the rock. The quartz grains are fractured. The quartz grains display undulatory as well as non-undulatory extinction. The contacts between quartz grains are either planer, suture and tangential.

The relative abundance of feldspar in sandstone is up to $6 \%$. The albite is up to $4 \%$ and the microcline forms up to $1 \%$. The micro perthite forms at least $1 \%$ of the rock.

The rock fragments form up to $38 \%$ of the rock. The mafic volcanic rock fragments are up to $9 \%$. In volcanic rock fragments the plagioclase phenocrysts form porphyritic texture in fine grained matrix. The quartzmica schists are up to $19 \%$, limestone fragments are up to $5 \%$ and sandstone clasts are up to $1 \%$, while the siltstone forms up to $2 \%$ of the rock. The quartzites fragments are up to $2 \%$. In quartzite fragments, the quartz grains are sutured togather.

The other mineral grains present in accessory amount are biotite, muscovite, chlorite and hornblende. The biotite is up to $2 \%$, muscovite is up to $1 \%$. The muscovite is deformed and altered. The mineral chlorite and hornblende are found in trace amount.

The clay matrix in sandstone is up to $9 \%$. The calcite cement is up to $13 \%$.

\subsection{Sample No. P-2 (1) Graywacke}

\subsubsection{Microscopic Features}

The quartz is dominantly monocrystalline, polycrystalline, stretched, round and very angular. The stretched grains indicate that their source material is high grade metamorphic rocks (Gneisses). The contacts between quartz grains are planer. The quartz grains are fractured. The quartz is of metamorphic and igneous origin. The replacement of quartz by calcite is common. The quartz grains form up to $29 \%$ of the rock. The monocrystalline quartz grains are up to $22 \%$, the polycrystalline quartz grains are up to $5 \%$ and the stretched quartz grains form up to $2 \%$ of the rock.

The feldspar forms up to $9 \%$ of the rock and includes albite is up to $5 \%$, perthite up to $1 \%$ and the microcline up to $3 \%$. Most of the feldspar grains are altered in to clays and sericite.

The rock fragments are the most dominant constituents of sandstone. Among rock fragments, volcanics, quartz-mica schists, quartzite clasts, carbonate fragments, reworked sandstone and the clasts of intraformational siltstone are abundant. The mafic volcanic rock fragments are up to $6 \%$. The quartz-mica schists are up to $18 \%$ and strongly foliated. The rock fragments of quartzite are up to $3 \%$. In quartzite fragments, the quartz grains are strongly sutured. The limestone fragments form up to $9 \%$ of the rock. The clasts of reworked sandstone are up to $2 \%$ while the intraformational siltstone is at least $1 \%$.

The minerals biotite, muscovite and chlorite are present as accessory grain. The biotite is at least $1 \%$ and also altered to chlorite. The chlorite is up to $1 \%$. The muscovite is also $1 \%$.

The clays form up to $8 \%$ matrix of sandstone. The calcite cement is up to $12 \%$. Most of the framework grains float on calcite cement.
5.24 Sample No. P-2 (2) Graywacke

\subsubsection{Microscopic Features}

The quartz grains are monocrystalline, polycrystalline and stretched. The quartz grains are very angular and sub rounded to rounded in form. The contacts between quartz grains are planer and suture. The quartz grains with undulatory as well as non-undulatory extinctions are common. The quartz grain forms up to $26 \%$ of the rock. The monocrystalline quartz grains are up to $18 \%$ and the polycrystalline quartz grains are up to $6 \%$. The stretched quartz grains form up to $2 \%$ of the rock.

The feldspar grains form up to $11 \%$ of the rock. The albite, microcline and perthite are common. The albite is up to $6 \%$, the perthite is up to $3 \%$ and the microcline forms up to $2 \%$ of the rock.

The rock fragments are another dominant constituent of sandstone. Among rock fragments, volcanic clasts, mica schists, quartzites, limestone fragments, reworked sandstone, intraformational siltstone and mudstone are abundant. The clasts of mafic volcanic rock fragments are up to $8 \%$ of the rock. The metamorphic rock fragments are up to $19 \%$ of the rock. The quartz-mica schists are up to $17 \%$ while the quartzite forms at least $2 \%$ of the rock. Similarly, the quartz grains are strongly sutured in quartzite. The limestone fragments form up to $8 \%$ of the rock. The siliciclastic rock particles include the fragments of reworked sandstone up to $2 \%$, intraformational siltstone up to $2 \%$ and mudstone at least $1 \%$.

The minerals chlorite, biotite and muscovite are present as accessory grains. The mineral chlorite is found as traces. The chlorite appears green in transmitted light. The biotite is up to $1 \%$ and muscovite each forms up to $2 \%$ of the rock.

The clays matrix in sandstone is up to $9 \%$. The calcite cement is up to $9 \%$. The chalcedony also acts as cement in sandstone. The chalcedony is up to $2 \%$.

\subsection{Sample No. AP-1 Litharenite}

\subsubsection{Microscopic Features}

The quartz grains are monocrystalline, polycrystalline and stretched. The quartz grains are of igneous or metamorphic origin. The quartz grains exhibit planer, suture and concavo-convex contacts. The quartz grains are fractured. The quartz grains are very angular, sub rounded and rounded. The quartz grains form up to $39 \%$ of the rock. The monocrystalline quartz grains are up to $34 \%$, the polycrystalline quartz grains are up to $4 \%$ and the stretched quartz grains form up to $1 \%$ of the rock.

The feldspar is another dominant mineral in sandstone that form up to $9 \%$ of the rock. The albite is up to $4 \%$, the microcline is up to $3 \%$ and the perthite forms up to $2 \%$ of the rock. Most of the feldspar grains are altered to secondary minerals.

The rock fragments form up to $32 \%$ of the rock. Among rock fragments, micaschists, volcanic clasts, limestone fragments, reworked sandstone, clasts of intraformational mudstone and siltstone are common. The strongly foliated quartz-mica schists are up to $11 \%$. In volcanic rock fragments, the plagioclase phenocrysts are embedded in fine grained matrix. The volcanic rock fragments are up to $5 \%$ in the rock. The fragments of limestone are up to $12 \%$ while the dolomite fragments are at least $3 \%$. The siliciclastic are sandstone fragments up to $1 \%$, mudstone clasts up to $2 \%$ and siltstone clasts up to $1 \%$.

The mineral biotite, hornblende and muscovite are present in minor amount. The minerals biotite, muscovite and hornblende each with $1 \%$ abundance are common.

The clay matrix in sandstone is up to $4 \%$ in the rock. The calcite cement is up to $13 \%$.

\subsection{Sample No. AP-2 Litharenite}

\subsubsection{Microscopic Features}

The quartz grains are monocrystalline, polycrystalline as well as stretched. The majority of quartz grains are round. The contacts between quartz grains are both planer and tangential. In tangential contacts the grains boundaries meet at right angle. The quartz grains are of igneous and metamorphic origin. The quartz grains form up to $40 \%$ of the rock. The monocrystalline quartz grains are up to $35 \%$, the polycrystalline grains are up to $4 \%$ and the stretched quartz grains form up to $1 \%$ of the rock. 
The feldspar forms up to $13 \%$ of the rock. The feldspars include albite (4\%), perthite (2\%), microcline (6\%) and microperthite (1\%). Most of the feldspar grains are altered in to secondary minerals.

The rock fragments in sandstone form up to $31 \%$ of the rock. The rock fragments depict a great variety in the form of volcanic clast, quartz-mica schists, quartzite and limestone fragments. In volcanic rock fragments the plagioclase phenocrysts are embedded in the fine-grained matrix. The volcanic rock fragments are up to $9 \%$. The stretched and strongly foliated quartz-mica schists form up to $12 \%$ of the rock. The strongly sutured quartz grains control the morphology of quartzite. The limestone fragments are up to $9 \%$. The clasts of intraformational mudstones are up to $1 \%$.

The other minerals present in accessory amount are biotite, muscovite, hornblende and chlorite. The biotite and muscovite each forms up to $1 \%$ of the rock. The muscovite is deformed and altered. The mineral hornblende and chlorite occur in trace amount.

The clays matrix in sandstone is up to $4 \%$ in the rock. The calcite acts as cementing material for framework grains. The calcite cement is up to $10 \%$.

\subsection{Sample No. P-4 Litharenite}

\subsubsection{Microscopic Features}

The quartz grains form up to $38 \%$ of the rock. The monocrystalline quartz grains are up to $31 \%$, the polycrystalline quartz grains are up to $5 \%$ while the remaining stretched quartz grain form up to $2 \%$ of the rock.

The feldspar forms up to $12 \%$ of the rock. The feldspar is albite, perthite and microcline. The albite is up to $7 \%$, the perthite is up to $3 \%$ while the microcline forms up to $2 \%$ of the rock.

The rock fragments constitute up to $32 \%$ of the rock. Among rock fragments, the volcanic clasts, limestone fragments, quartz-mica schists and quartzite clasts occur in the rock. The volcanic rock fragments are up to $6 \%$ in the rock. In volcanic rock fragments the plagioclase phenocrysts are embedded in fine grained matrix. The limestone fragments are up to $4 \%$. The strongly foliated quartz-mica schists are up to $19 \%$. While the quartzite rock fragments form up to $3 \%$ of the rock.

The minerals biotite is up to $2 \%$ and muscovite forms up to $1 \%$ in the rock. The chlorite, hornblende and tourmaline are found in trace amount.

The clay matrix in sandstone is up to $3 \%$ in the rock. The calcite cement in sandstone is up to $12 \%$.

\subsection{Sample No. Topa Graywacke}

\subsubsection{Microscopic Features}

The quartz grains are fractured, very angular to subrounded. The monocrystalline quartz grains are up to $21 \%$, the polycrystalline quartz grains are up to $4 \%$ while the stretched quartz grains form up to $2 \%$ of the rock. The undulatory as well as non-undulatory extinctions are common in quartz grains.

The feldspar is another dominant mineral in sandstone. The feldspar forms up to $7 \%$ of the rock. The albite is up to $5 \%$ while the microcline forms up to $2 \%$ of the rock.

The rock fragments are of igneous, sedimentary and metamorphic origin and constitutes up to $42 \%$ of the rock. The volcanic rock fragments are up to $5 \%$. In volcanic rock fragments the plagioclase phenocrysts are embedded in the fine-grained matrix. Among sedimentary rocks, limestone fragments are common. The limestone fragments are up to $21 \%$. The metamorphic rock fragments are of $16 \%$. The strongly quartz-mica schists form up to $15 \%$ of the rock. The quartzite rock fragments are up to $1 \%$. In the quartzite rock fragments, the quartz grains are sutured together.

The minerals biotite, muscovite, hornblende and hematite are also present. The relative abundance of each mineral grain is as follows. The biotite is up to $1 \%$. The muscovite is up to $2 \%$. The chlorite, hornblende and tourmaline occurs in minor amount. The opaque mineral hematite is up to $1 \%$.

The clays act as matrix in sandstone. The clays are up to $7 \%$. The dominant cementing material is calcite. The calcite is up to $13 \%$.

\subsection{Sample No. GN-1 Graywacke}

\subsubsection{Microscopic Features}

The quartz grains are fractured. The monocrystalline quartz grains are up to $24 \%$, the polycrystalline quartz grains are up to $6 \%$ and the stretched quartz grains form up to $2 \%$ of the rock. Hence the quartz grains are up to $32 \%$. The quartz grains are large in size.

The feldspar constitutes up to $12 \%$. The albite is up to $7 \%$, the microcline is up to $3 \%$ while the perthite forms up to $2 \%$ of the rock. Most of the feldspar grains are altered to secondary minerals.

The rock fragments of igneous, sedimentary and metamorphic rocks are the dominant constituent of sandstone that form up to $37 \%$ of the rock. The mafic volcanic rock fragments are up to $10 \%$. In the volcanic rock fragments, the plagioclase phenocrysts embedded in the fine-grained matrix represents the idiosyncratic character of basalt. The limestone fragments are up to $13 \%$ in the rock. The metamorphic rock fragments are up to $22 \%$. The strongly foliated quartz-mica schists are up to $19 \%$. The quartzite rock fragments form up to $3 \%$ of the rock. In quartzite rock fragments, the quartz grains are sutured together.

Other mineral grains include biotite, muscovite and zircon. The biotite is up to $1 \%$. The mineral muscovite and zircon each with $1 \%$ abundance are common.

The clays act as matrix in sandstone. The matrix of sandstone is up to $6 \%$. The calcite acts as the cementing material for framework grains. The calcite is up to $8 \%$. The chalcedony with plumose texture also acts as cementing material. The chalcedony forms up to $2 \%$ of the rock.

\subsection{Sample No. P-1 Graywacke}

\subsubsection{Microscopic Features}

The quartz grains constitute about $29 \%$ of the rock. The monocrystalline quartz grains are up to $20 \%$, the polycrystalline quartz grains are up to $7 \%$ while the stretched quartz grains form up to $2 \%$ of the rock.

The feldspar is up to $9 \%$ in the rock. The feldspar includes albite (4\%), microcline $(2 \%)$ and perthite $(3 \%)$ in the rock.

The rock fragments are the major constituents of sandstone that form up to $35 \%$ of the rock. The volcanic rock fragments are up to $12 \%$. The limestone fragments are up to $13 \%$. The dolomite fragments are up to $2 \%$. The metamorphic rock fragments are up to $10 \%$. The quartz-mica schists form up to $9 \%$ of the rock. The quartz grains are sutured together in quartzite. The quartzite rock fragments form up to $1 \%$ of the rock.

The accessory mineral grains in the rock include biotite, muscovite and chlorite. The mineral biotite is up to $3 \%$. The muscovite and chlorite are found in trace amount.

The clay matrix in sandstone is up to $6 \%$. The framework grains are strongly held in position by calcite cement. The calcite forms up to $18 \%$ of the rock.

\section{CONCLUSIONS}

The research work agrees with the early findings of geologists and indicates that the major minerals and rock fragments exist in excess amount inside the rocks. On the other hand, the accessory minerals occur in scanty amount. The textural immaturity in the rock is revealed by the angularity of quartz grains. Moreover, zircon invasions in quartz and hematite coatings around quartz grains indicate that the quartz is older in chronology. Furthermore, the hematite indicates oxidizing and pyrite indicates reducing environment of deposition. It means that the tectonic activities have brought them together in the depositional sites. The undulation in quartz and myrmekite texture in perthite and zoning in feldspar grains reflects their igneous origin. The rock fragments of basalt and granites confirm the degradation of igneous rocks. The compositions of rock fragments indicate high relief source areas. The deformation in muscovite indicates mechanical compaction during diagenesis. The clay and altered mica (sericite) are formed by the expanse of argillaceous matrix and calcite and silica precipitated in the pore spaces of rocks served as the cement of the rock.

The geology of the region as studied during section measurement (Figure 3) in the field indicates that the Murree and Nagri Formations are well exposed in the area. 


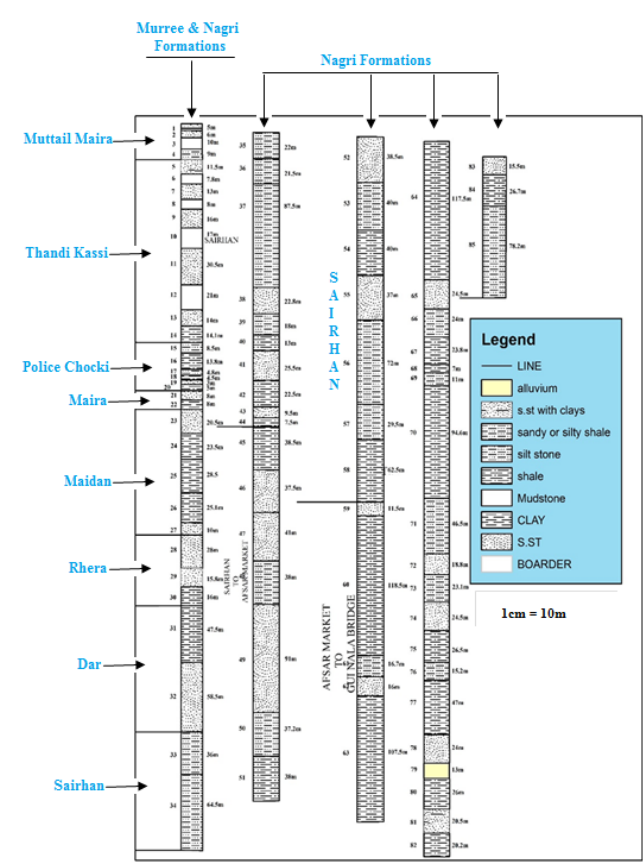

Figure 3: The stratigraphic section of the project area. In Muttail Maira, Thandi Kassi, Police Chocki and Maira the Murree Formation is exposed as compared to the remaining areas with the best exposures of the Nagri Formation. The police Chocki and Maira (not shown on the map) are the local geographic areas adjacent to the Thandi Kassi. In section measurement only one limb of the fold and one block of the fault were measured.

\section{REFERENCES}

[1] Iqbal, A., Baig, M. S., Akram, M., Rahim, S., and Quershi, A.A. 2007. Measurement of Radon concentration using SSNTD in dwelling of Rawalakot area, Azad Jammu and Kashmir, Sub-Himalayas, Pakistan, 17 (3), 392-398.

[2] Meddlicot, H. B. 1876. Notes on the sub-Himalayan series of Jammu Hills. Records of the Geological Survey of India, 9, 49.

[3] Lydekker, R. 1876. Notes on geology of the Pir Panjal and neighbouring Districts. Geological Survey India Recruitment, 9 (2), 155-162.

[4] Middlemiss, C. S. 1896. The geology of Hazara and black mountains. Memoirs of the Geological Survey of India, 26, 302.

[5] Chaudhary, M. N., and Ashraf, M. 1980. The volcanic rocks of Poonch district, Azad Kashmir. Special Issue, Geology Bulletin University Peshawar, 131 (152), 121-128.

[6] Kazmi, A. H., and Jan, M. Q. 1997. Geology and tectonics of Pakistan, 67-84.

[7] Kazmi, A. H., and Rana, R. A. 1982. Tectonic map of Pakistan. Geological Survey of Pakistan, Scale,1:2000000.

[8] Lindholm, R.C., and Finkelman, R.B. 1972. Calcite staining: semi quantitative determination of ferrous iron: Noted. Journal of Sedimentary Petrology, 42 (1), 239-245.

[9] Yasin, M. 2014. Petrography and Sedimentology of Neogene sediments in Mang and adjoining areas in the Sub-Himalayas, Azad Jammu and Kashmir, Pakistan, Unpublished MS Thesis, University of Azad Jammu and Kashmir, Muzaffarabad, 213. 